\title{
Differential regulation of catecholamine synthesis and transport in rat adrenal medulla by fluoxetine treatment
}

\author{
NATASA SPASOJEVIC, PREDRAG JOVANOVIC and SLADJANA DRONJAK \\ Institute of Nuclear Sciences "Vinca", Department of Molecular Biology and Endocrinology, \\ University of Belgrade, P.O Box 522-090, 11000, Belgrade, Serbia \\ Manuscript received on October 14, 2013; accepted for publication on September 6, 2014
}

\begin{abstract}
We have recently shown that chronic fluoxetine treatment acted significantly increasing plasma norepinephrine and epinephrine concentrations both in control and chronically stressed adult male rats. However, possible effects of fluoxetine on catecholamine synthesis and re-uptake in adrenal medulla have been largely unknown. In the present study the effects of chronic fluoxetine treatment on tyrosine hydroxylase, a rate-limiting enzyme in catecholamine synthesis, as well as a norepinephrine transporter and vesicular monoamine transporter 2 gene expressions in adrenal medulla of animals exposed to chronic unpredictable mild stress (CUMS) for 4 weeks, were investigated. Gene expression analyses were performed using a real-time quantitative reverse transcription-PCR. Chronically stressed animals had increased tyrosine hydroxylase mRNA levels and decreased expression of both transporters. Fluoxetine increased tyrosine hydroxylase and decreased norepinephrine transporter gene expression in both unstressed and CUMS rats. These findings suggest that chronic fluoxetine treatment increased plasma catecholamine levels by affecting opposing changes in catecholamine synthesis and uptake.
\end{abstract}

Key words: adrenal medulla, antidepressant, gene expression, norepinephrine transporter, tyrosine hydroxylase.

\section{INTRODUCTION}

The syndrome of major depression, particularly the melancholic type, potentially reflects dysregulation of the stress response (Chrousos and Gold 1998). The body responds to stress by activating the sympathoadrenal system and secreting epinephrine (E) and norepinephrine (NE) in the "fight-orflight" response (Cannon 1929). Elevated levels of catecholamines were also detected in patients with signs of depression (Hamer et al. 2007). Increased release of catecholamines during stress could result from the changes in catecholamine

Correspondence to: Natasa Spasojevic

E-mail: snatally@vinca.rs synthesis, storage and/or release in adrenal medulla. Tyrosine hydroxylase $(\mathrm{TH})$ is a ratelimiting enzyme in catecholamine biosynthetic process. Catecholamines are stored in secretory granules of adrenal chromaffin cells and released by regulated exocytosis. Two membrane carriers are involved in their subsequent reuptake and storage. The antidepressant- and cocaine-sensitive $\mathrm{Na}^{+}, \mathrm{Cl}^{-}$-dependent norepinephrine transporter (NET) functions at the plasma membrane, mediates both the clearance of catecholamines and their recovery into the vesicles for subsequent re-use. Immunocytochemistry of rat adrenal tissue showed that NET staining was co-localized with $\mathrm{TH}$ in 
medullary chromaffin cells (Kippenberger et al. 1999). The uptake of monoamines from the cytoplasm into secretory granules is mediated by vesicular monoamine transporters (VMATs) and requires an ATPase-generated proton gradient (Erickson et al. 1996, Eiden 2000). Several studies indicate that VMATs play a critical role not only in sorting, storing and releasing of monoamines, but also in fine-tuning of neuronal and endocrine informational output (Henry et al. 1994, Eiden et al. 2004). Two isoforms of the vesicular monoamine transporter (VMAT1 and VMAT2) have been characterized in rodent tissue (Erickson et al. 1992). VMAT1 is widely expressed in all adrenal chromaffin cells, while VMAT2 is colocalized with TH enzyme (Tillinger et al. 2010). A subpopulation of chromogranin A -expressing chromaffin cells of the adrenal medulla also express VMAT2 (Weihe et al. 1994). Chromogranins are highly efficient systems directly involved in monoamine accumulation and in the exocytotic release of catecholamines (Borges et al. 2010).

Numerous authors observed the changes in the synthesis of catecholamines in the brain after fluoxetine treatment, but the data on the effect of this drug on catecholamine synthesis in the adrenal glands, are sparse. While administration of tricyclic antidepressants causes decrease (Zavosh et al. 1999) or in contrast, increase of NET mRNA (Szot et al. 1993), SSRI antidepressants including fluoxetine have been reported to express no effect on NET mRNA expression (Benmansour et al. 2004, Shinkai et al. 2005). Blardi et al. (2005) detected increased levels of catecholamines in depressed patients receiving fluoxetine (SSRI) for 40 days. We have also found that chronic fluoxetine treatment leads to a marked increase in the amount of plasma catecholamines both in control and stressed rats (Dronjak et al. 2007).

These results indicated the need to explore possible effects of fluoxetine on adrenal function using a chronic unpredictable mild stress (CUMS) paradigm in rats. The CUMS model was chosen because it induces many behavioral and biochemical characteristics that are similar to human depression, including anhedonia, reduced body weight and glucocorticoid hypersecretion (Willner et al. 1992, Papp et al. 1994, Dronjak et al. 2007). All these symptoms are reversed by chronic antidepressant treatment, indicating that this model has good predictive validity (Muscat et al. 1992). In order to examine whether the effects of fluoxetine on plasma catecholamine levels could be due to changes in their synthesis and/or release in adrenal medulla, the present study was undertaken to determine differences in TH, VMAT2 and NET gene expression in control and stressed rats after chronic fluoxetine treatment.

\section{MATERIALS AND METHODS}

ANIMALS

Adult Wistar male rats weighing 280-320g at the onset of experiments and maintained in a temperature-controlled room $\left(21 \pm 1.0^{\circ} \mathrm{C}\right)$ and $12 \mathrm{~h} / 12 \mathrm{~h}$ light/dark cycle, were used. The care was taken to minimize the pain and discomfort of the animals according to the recommendations of the Ethical Committee of the "Vinca" Institute, Belgrade, which are in accordance with the Guide for Care and Use of Laboratory Animals of the National Institute of Health, Bethesda, MD, U.S.A. Fluoxetine (fluxilan ${ }^{\circledR}$, Aeigis LTD, Cyprus) dissolved in sterile water and sonicated for approximately $10 \mathrm{~min}$, was prepared ex tempore. Animals that were subjected to CUMS, according to method by Grippo et al. (2002), received daily injections of vehicle (sterile water) or fluoxetine $(10 \mathrm{mg} / \mathrm{kg})$ by i.p. route during 4 weeks. The fluoxetine dose was selected based upon the work of Reneric et al. (2002) and our previous study (Spasojevic et al. 2008). The control group was also receiving daily injections of vehicle. Upon completion of 4 weeks, the animals exposed to CUMS and controls were decapitated, the adrenal medulla rapidly dissected, frozen in liquid nitrogen and stored at $-70^{\circ} \mathrm{C}$ until analyzed. 


\section{RNA ISOLATION AND CDNA SYNTHESIS}

Total RNAs were isolated using TRIZOL reagent (Invitrogen, CA, U.S.A.). Reverse transcription was performed using Ready-To-Go You-Prime First-Strand Bead (AP, Biotech) and pd $(\mathrm{N})_{6}$ primer according to manufacturer's protocol.

REAL-TIME RT-PCR

TaqMan PCR assays were carried out using Assayon-Demand Gene Expression Products (Applied Biosystems, USA) for TH (ID:Rn00562500-m1), NET (ID: Rn00580207_m1) and VMAT2 (ID: Rn00564688_m1). The reactions were performed in a $25 \mu \mathrm{l}$ reaction mixture containing $1 \mathrm{x}$ TaqMan Universal Master Mix with AmpErase UNG, 1x Assay Mix (Applied Biosystems) and cDNA template (10 ng of RNA converted to cDNA). PCR reactions were performed in the ABI Prism 7000 Sequence Detection System at $50^{\circ} \mathrm{C}$ for $2 \mathrm{~min}$, $95^{\circ} \mathrm{C}$ for $10 \mathrm{~min}$, followed by 40 cycles at $95^{\circ} \mathrm{C}$ for $15 \mathrm{sec}$ and $60^{\circ} \mathrm{C}$ for $1 \mathrm{~min}$. A reference, endogenous control, was included in each analysis to correct the differences in the inter-assay amplification efficiency and all transcripts were normalized to cyclophyline A (ID:Rn 00690933) expression. Quantification was done using the $2^{-\Delta \Delta C t}$ method according to Livak and Schmittgen (2001).

STATISTICAL ANALYSIS

The results are reported as means \pm S.E.M. Significance of the differences between the groups in gene expression levels of the examined catecholamine synthesising enzyme and transporters were estimated by Two-way ANOVA test, followed by the Tukey post hoc test. Statistical significance was accepted at $\mathrm{p}<0.05$.

\section{RESULTS}

The exposure of rats to CUMS displayed low, although significant rise of $43 \%(\mathrm{p}<0.05)$ in $\mathrm{TH}$ mRNA levels (Fig.1). Fluoxetine treatment also significantly increased TH mRNA expression both in control and stressed animals (by $43 \%$ and $34 \%$ respectively, $\mathrm{p}<0.05$ ) in comparison to vehicle group.

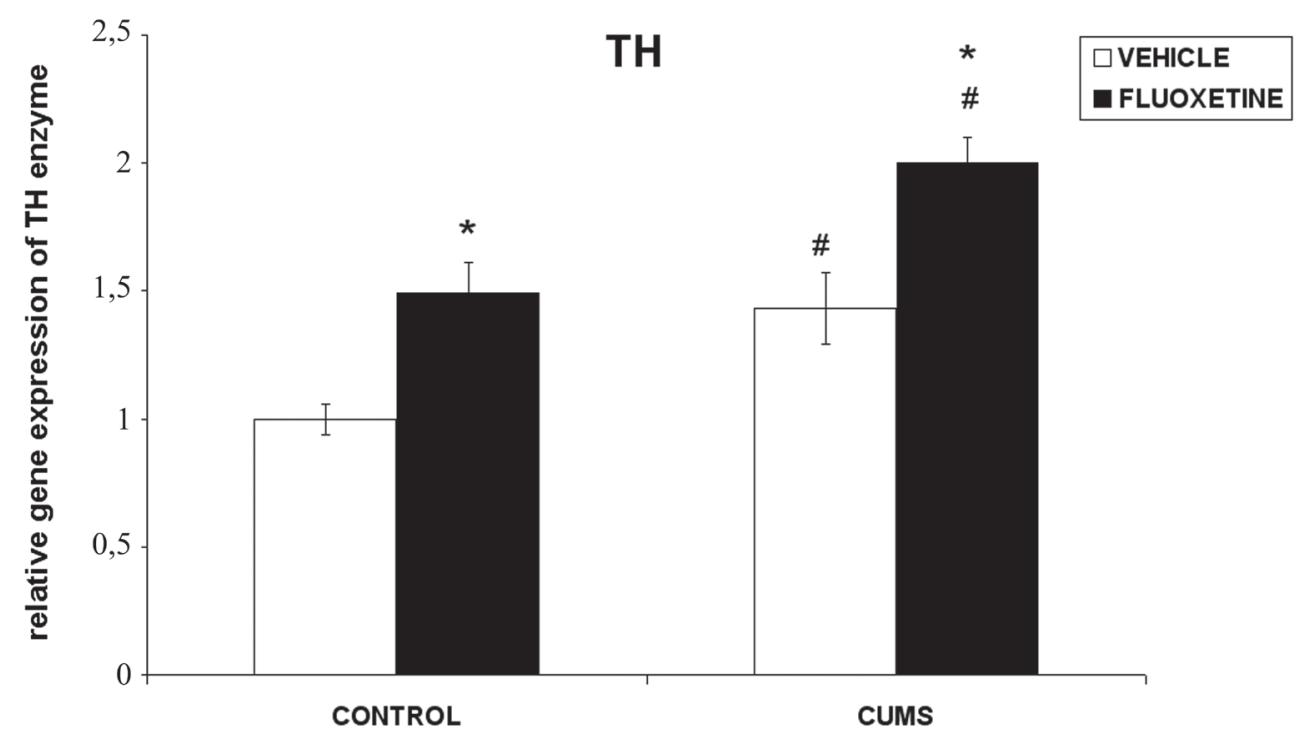

Figure 1 - Effect of chronic treatment with fluoxetine on tyrosine hydroxylase (TH) mRNA levels in adrenal medulla of rats exposed to CUMS for 4 weeks. The values are means \pm S.E.M. of 6-8 rats. Statistical significance: \# $<<0.05$ CUMS vs. unstressed control; * $\mathrm{p}<0.05$ placebo $v s$. fluoxetine (Tukey test). The final result was expressed as fold change relative to the calibrator and normalized to cyclophyline A. 
Analysis of the data also displayed a significant chronic stress-related change $\left(\mathrm{F}_{(1,16)}=18.98\right.$, $\mathrm{p}<0.001)$ in VMAT2 mRNA levels. VMAT2 mRNA expression in medulla was decreased by $41 \%$ $(\mathrm{p}<0.01)$ after exposure of animals to CUMS, while fluoxetine expressed no effect (Fig. 2).

The results presented in Fig. 3. indicate a major influence of CUMS $\left(\mathrm{F}_{(1,16)}=17.94, \mathrm{p}<0.001\right)$ on
NET mRNA levels in the medulla. Post-hoc analysis demonstrated a significant decrease in stressed rats (by $41 \%, \mathrm{p}<0.05$ ) in comparison to the controls. Long-term administration of the antidepressant altered NET mRNA content $\left(\mathrm{F}_{(1,16)}=20.72, \mathrm{p}<\right.$ 0.001) (Fig. 3). Fluoxetine significantly diminished NET mRNA levels both in control and stressed rats (by $43 \%, \mathrm{p}<0.01$ and $50 \%, \mathrm{p}<0.05$, respectively).

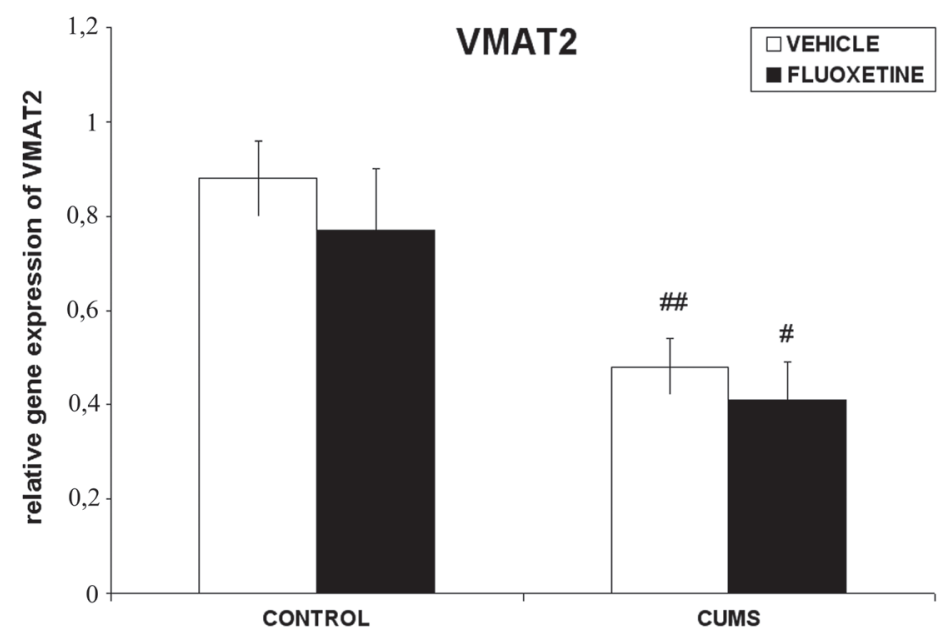

Figure 2 - Effect of chronic treatment with fluoxetine on vesicular monoamine transporter 2 (VMAT2) mRNA levels in adrenal medulla of rats exposed to CUMS for 4 weeks. The values are means \pm S.E.M. of $6-8$ rats. Statistical significance: \# $p<0.05$; \#\# $\mathrm{p}<0.01$ CUMS vs. unstressed control (Tukey test). The final result was expressed as fold change relative to the calibrator and normalized to cyclophyline A.

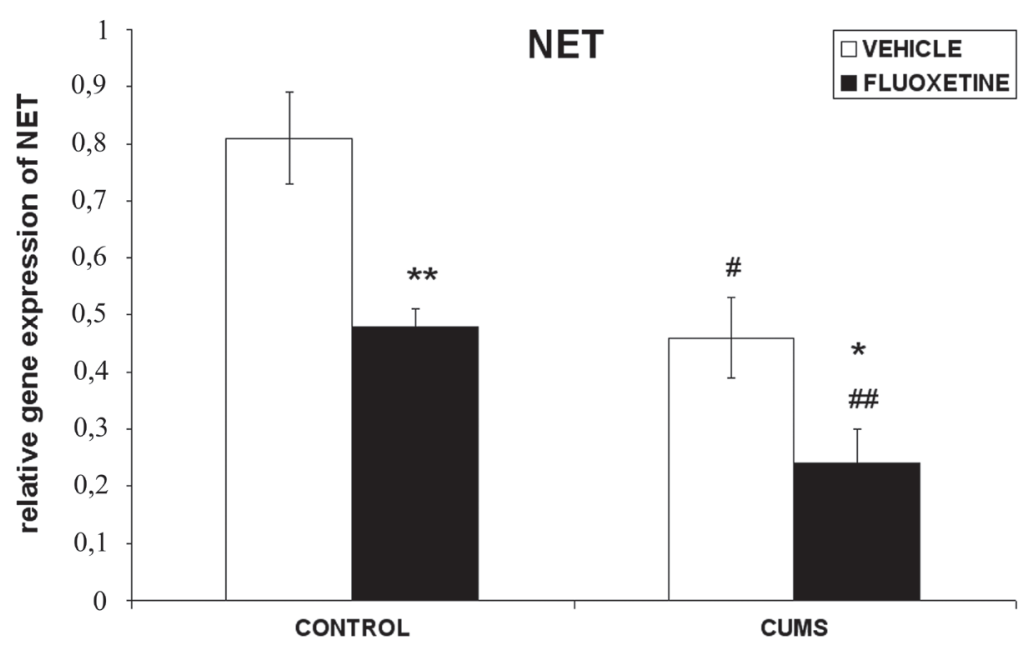

Figure 3 - Effect of chronic treatment with fluoxetine on norepinephrine transporter (NET) mRNA levels in adrenal medulla of rats exposed to CUMS for 4 weeks. The values are means \pm S.E.M. of 6-8 rats. Statistical significance: \# $<<0.05$; \#\# $\mathrm{p}<0.01 \mathrm{CUMS} v \mathrm{~s}$. unstressed control; $* \mathrm{p}<0.05, * * \mathrm{p}<0.01$ placebo $v$ s. fluoxetine (Tukey test). The final result was expressed as fold change relative to the calibrator and normalized to cyclophyline A. 


\section{DISCUSSION}

In the present study, the effects of fluoxetine a widely used antidepressant on the levels of mRNAs encoding $\mathrm{TH}$, a rate-limiting enzyme in catecholamine biosynthesis and two transporters NET and VMAT2 in adrenal medulla of CUMS rats, were examined. CUMS led to increased TH mRNA levels in the adrenal medulla. Similar to our results, Serova et al. (1998) had previously found elevated basal levels of TH mRNA in the adrenal medulla in Flinder's Sensitive Line (FSL), a genetic rat model of depression. Numerous authors have confirmed corticosterone regulation of TH mRNA (Kumai et al. 2000, Tank et al. 1986). Animals exposed to CUMS were shown to have elevated plasma corticosterone levels (Dronjak et al. 2007), which could be the cause of the observed changes in the TH gene expression. Among SSRIs, fluoxetine uniquely increased extracellular NE and serotonin (5-HT) levels (Pozzi et al. 1999, Bymaster et al. 2002). According to Brady et al. (1992) and Heydendael and Jacobson (2010) this antidepressant stimulates the synthesis of NE in the brain by increasing TH mRNA levels. Our results also demonstrated that repeated fluoxetine administration led to increased expression of TH mRNAs in the adrenal medulla. Thome et al. (2000) reported that chronic treatment of rats with a number of clinically effective antidepressants significantly increased cAMP-controlled gene transcription, as well as phosphorylation (and activation) of the transcription factor, a cAMP response element binding protein (CREB), in several brain regions. Fluoxetine was shown to increase cAMP levels (Edgar et al. 1999) and to promote CRE-dependent gene transcription in rat brain (Duman 2004). This transcription factor is essential for the proper $\mathrm{TH}$ gene regulation in the adrenal gland (Sabban et al. 2004). Besides this signaling pathway, Shinkai et al. (2007) reported that milinacipran, a serotonin norepinephrine reuptake inhibitor, activates $\mathrm{TH}$ through a p44/42 mitogenactivated protein kinase (MAPK)-dependent pathway in cultured bovine adrenal medullary cells.
Our results show that VMAT2 and NET mRNA levels are reduced in rats exposed to CUMS. Tillinger et al. (2010) have recently observed that VMAT2 is up-regulated in chromaffin cells in vivo following immobilization stress. The differences of these and our results related to VMAT2 gene expression could be ascribed to the differences in the types of stress paradigms. On the other hand, our finding of reduced NET mRNA levels in medulla of chronically stressed rats agrees well with that of Cubells et al. (1995) who reported that reserpineinduced activation led to increased TH mRNA levels but at the same time to a significant decrease in NET mRNA levels both in locus coeruleus and adrenal medulla. Wakade et al. (1996) provided the evidence that glucocorticoids decreased NET mRNA and functional activity in rat chromaffin cells maintained in culture, primarily through the changes in activator protein-1 (AP-1) motif/binding protein interactions. Reduced expression of these transporters could result from increased demand for catecholamine secretion, because it would decrease the reuptake of NE and thus enhance NE release into the circulation. Finally, the observed opposite TH and NET gene expression regulation in the adrenals of CUMS rats would be anticipated to contribute to the maintenance of stress response.

Yasumoto et al. (2009) suggested that fluoxetine was able to deplete catecholamines by inhibiting the activity of VMAT2. However, our results did not indicate the impact of this drug on the gene expression of VMAT2 transporter. In the present experiments we detected a significant decrease in NET mRNA after chronic fluoxetine treatment. This is the first direct evidence clearly demonstrating the effect of fluoxetine on gene expression of NET in rat adrenal medulla. These results indicate that we should not exclude the possibility that the inhibition of NE uptake, contributes to the increased NE concentration in plasma, induced by fluoxetine. Rodent NE transporter promoter does not possess a cAMP response element, but it does have an 
AP-1 site (Fritz et al. 1998) and immediate-early gene products that bind to this site (Fos and Jun) and can be induced by cAMP (Herdegen 1996). Direct treatment of bovine adrenal chromaffin cells in vitro with the agents that elevate or mimic intracellular cAMP was reported to reduce NE uptake (Bunn et al. 1992). Besides, nerve growth factor (NGF) and other neurotrophins were also present in developing and mature adrenal chromaffin cells (Suter-Crazzolara et al. 1996). After treatment of rat pheochromocytoma cell line PC12 with NGF, Ikeda et al. (2001) demonstrated decreased NET mRNA, but increased TH mRNA levels. On the other hand, chronic application of fluoxetine led to NFG enhancement in the frontal cortex (Hassanzadeh and Hassanzadeh 2009).

Amplifying catecholaminergic signaling, observed after fluoxetine treatment, could be associated with cardiovascular side effects. Rotondi et al. (2011) reported the clinical case in which duloxetine may have precipitated "tako-tsubo" cardiomyopathy by increasing plasma catecholamine concentration. Considering the fact that we have recently also recorded a significant increase of $\beta_{1}$-adrenoreceptor mRNA levels in the heart of CUMS rats treated with fluoxetine (Spasojevic et al. 2011), these findings should be taken into account when treating depressed patients with concomitant cardiac disease. Further studies are necessary to confirm our data and establish the functional significance of these results.

\section{ACKNOWLEDGMENTS}

This work was supported by the Ministry of Education and Science of the Republic of Serbia, Contract No. 173044.

\section{RESUMO}

Mostramos recentemente que o tratamento crônico com fluoxetina agiu de forma a aumentar significativamente as concentrações de noradrenalina e adrenalina no plasma tanto nos controles quanto em ratos machos adultos cronicamente estressados. No entanto, os possíveis efeitos da fluoxetina na síntese de catecolaminas e recaptação na medula adrenal são em grande parte desconhecidos. No presente estudo, os efeitos do tratamento crônico com fluoxetina sobre a tirosina hidroxilase, uma enzima limitante da velocidade de síntese de catecolaminas, bem como a expressão gênica de um transportador de norepinefrina e do Transporter 2 de monoamina vesicular na medula adrenal foram investigados em animais expostos ao estresse leve crônico imprevisível (CUMS) durante 4 semanas. Análises de expressão gênica foram realizadas utilizando transcrição reversaPCR quantitativa em tempo real. Animais com estresse crônico tiveram níveis aumentados de mRNA para tirosina hidroxilase e a expressão diminuída de ambos os transportadores. A fluoxetina aumentou a tirosina hidroxilase e diminuiu a expressão do gene transportador de norepinefrina tanto em ratos não estressados quanto em CUMS. Estes resultados sugerem que o tratamento crônico com fluoxetina aumentou os níveis plasmáticos de catecolaminas por afetar alterações opostas na síntese e absorção de catecolaminas.

Palavras-chave: medula adrenal, antidepressivos, expressão gênica, transportador de norepinefrina, tirosina hidroxilase.

\section{REFERENCES}

Benmansour S, Altamirano AV, Jones DJ, Sanchez TA, Gould GG, PARdon MC, Morilak DA AND Frazer A. 2004. Regulation of the noradrenaline transporter by chronic administration of antidepressants. Biol Psychiatry 55: 313-316.

Blardi P, De Lalla A, Auteri A, Iapichino S, Dell'erba A AND CASTROGiovanni P. 2005. Plasma catecholamine levels after fluoxetine treatment in depressive patients. Neuropsychobiology 51: 72-76.

Borges R, Díaz-Vera J, Domínguez N, Arnau MR AND MACHADO JD. 2010. Chromogranins as regulators of exocytosis. J Neurochem 114: 335-343.

BRADY LS, GOLD PW, HERKENHAM M, LYNN AB AND WHITFIELD HJ. 1992. The antidepressants fluoxetine, idazoxan and phenelzine alter corticotropin-releasing hormone and tyrosine hydroxylase mRNA levels in rat brain: therapeutic implications. Brain Res 572: 117-125.

BunN SJ, O'BRIEN KJ, BOYD TL AND POwIS DA. 1992. Pertussis toxin inhibits noradrenaline accumulation by bovine adrenal medullary chromaffin cells. Naunyn Schmiedebergs Arch Pharmacol 346: 649-656. 
Bymaster FP, Zhang W, Carter PA, Shaw J, Chernet E, PheBus L, Wong DT AND PERRY KW. 2002. Fluoxetine, but not other selective serotonin reuptake inhibitors, increases noradrenaline and dopamine extracellular levels in the prefrontal cortex. Psychopharmacology (Berl) 160: 353-361.

CANNON W. 1929. Organization of physiological homeostasis. Physiol Rev 9: 3900-3431.

Chrousos GP AND GOLD PW. 1998. A healthy body in a healthy mind - and vice versa - the damaging power of uncontrollable stress. J Clin Endocrinol Metabol 83: 1842-1845.

Cubells JF, Kim KS, BaKer H, Volpe BT, Chung Y, Houpt TA, WeSSEL TC AND JOH TH. 1995. Differential in vivo regulation of mRNA encoding the noradrenaline transporter and tyrosine hydroxylase in rat adrenal medulla and locus ceruleus. J Neurochem 65: 502-509.

DronjaK S, SpasojeVic N, GaVRILOVIC L and VARAGiC V. 2007. Effects of noradrenaline and serotonin reuptake inhibitors on pituitary-adrenocortical and sympathoadrenomedullar system of adult rats. Neuro Endocrinol Lett 28: 614-620.

DUMAN RS. 2004. Role of neurotrophic factors in the etiology and treatment of mood disorders. Neuromolecular Med 5: 11-25.

Edgar VA, STERIN-Borda L, CREMASCHI GA AND GENARO AM. 1999. Role of protein kinase $C$ and cAMP in fluoxetine effects on human T-cell proliferation. Eur J Pharmacol 372: 65-73.

EIDEN LE. 2000. The vesicular neurotransmitter transporters: current perspectives and future prospects. FASEB J 14: 2396-2400.

EIDEN LE, SCHÄFER MK, WEIHE E AND SCHÜTZ B. 2004. The vesicular amine transporter family (SLC18): Amine/ proton antiporters required for vesicular accumulation and regulated exocytotic secretion of monoamines and acetylcholine. Pflugers Arch 447: 636-640.

ERICKSON JD, EIDEN LE AND HOFFMAN BJ. 1992. Expression cloning of a reserpine-sensitive vesicular monoamine transporter. Proc Natl Acad Sci USA 89: 10993-10997.

ERICKSON JD, SCHÄFER MK, BONNER TI, EIDEN LE AND WeIHE E. 1996. Distinct pharmacological properties and distribution in neurons and endocrine cells of two isoforms of the human vesicular monoamine transporter. Proc Natl Acad Sci USA 93: 5166-5171.

FRITZ JD, JAYANTHI LD, THORESON MA AND BLAKELY RD. 1998. Cloning and chromosomal mapping of the murine noradrenaline transporter. J Neurochem 70: 2241-2251.

GRIPPO AJ, MOFFITT JA AND JOHNSON AK. 2002. Cardiovascular alterations and autonomic imbalance in an experimental model of depression. Am J Physiol Regul Integr Comp Physiol 282: 1333-1341.

HAMER M, TANAKA G, OKAMURA H, TSUdA A AND STEPTOE A. 2007. The effects of depressive symptoms on cardiovascular and catecholamine responses to the induction of depressive mood. Biol Psychol 74: 20-25.

HASSANZADEH P AND HASSANZADEH A. 2009. Effects of psychotropic drugs on nerve growth factor protein levels in the rat brain. Physiology and Pharmacology 13: 244-252.
Henry JP, Botton D, SAgne C, Isambert MF, Desnos C, Blanchard V, Raisman-Vozari R, KREJCI E, MASSOUlie J AND GASNIER B. 1994. Biochemistry and molecular biology of the vesicular monoamine transporter from chromaffin granules. J Exp Biol 196: 251-262.

HERDEGEN T. 1996. Jun, Fos, and CREB/ATF transcription factors in the brain: control of gene expression under normal and pathophysiological conditions. Neuroscientist 2: $153-161$.

HEYDENDAEL W AND JACOBSON L. 2010. Widespread hypothalamic-pituitary-adrenocortical axis-relevant and mood-relevant effects of chronic fluoxetine treatment on glucocorticoid receptor gene expression in mice. Eur $\mathrm{J}$ Neurosci 31: 892-902.

IKEDA T, KitayAma S, MORITA K AND DOHI T. 2001. Nerve growth factor down-regulates the expression of noradrenaline transporter in rat pheochromocytoma (PC12) cells. Brain Res Mol Brain Res 86: 90-100.

KIPPENBERGER AG, PALMER DJ, COMER AM, LIPSKI J, BurTON LD AND CHRISTIE DL. 1999. Localization of the noradrenaline transporter in rat adrenal medulla and PC12 cells: evidence for its association with secretory granules in PC12 cells. J Neurochem 73: 1024-1032.

Kumai T, Asoh K, TAteishi T, TANaKa M, Watanabe M, SHIMIZU H AND KoBAYASHI S. 2000. Involvement of tyrosine hydroxylase up regulation in dexamethasoneinduced hypertension of rats. Life Sci 67: 1993-1999.

LIVAK KJ AND SCHMITTGEN TD. 2001. Analysis of relative gene expression data using real-time quantitative PCR and the 2(-Delta Delta C(T)) Method. Methods 25: 402-408.

MusCAT R, PAPP M AND WILLNER P. 1992. Reversal of stress induced anhedonia by the atypical antidepressants, fuoxetine and maprotiline. Psychopharmacology (Berl) 109: 433-438.

PAPP M, KLIMEK V AND WiLlNER P. 1994. Effects of imipramine on serotonergic and beta adrenergic receptor binding in a realistic animal model of depression. Psychopharmacology (Berl) 114: 309-314.

POZZI L, INVERNIZZI R, GARAVAGLIA C AND SAMANIN R. 1999. Fluoxetine increases extracellular dopamine in the prefrontal cortex by a mechanism not dependent on serotonin: a comparison with citalopram. J Neurochem 73: 1051-1057.

RENERIC JP, BOUVARD M AND STINUS L. 2002. In the rat forced swimming test, chronic but not subacute administration of dual 5-HT/NA antidepressant treatments may produce greater effects than selective drugs. Behav Brain Res. 136: 521-532.

Rotondi F, Manganelli F, Carbone G and Stanco G. 2011. "Tako-tsubo" cardiomyopathy and duloxetine use. South Med J 104: 345-347.

Sabban EL, Nankova BB, Serova LI, Kvetnansky R and LIU X. 2004. Molecular regulation of gene expression of catecholamine biosynthetic enzymes by stress: sympathetic ganglia versus adrenal medulla. Ann N Y Acad Sci 1018: 370-377.

Serova L, SABban EL, ZANGen A, Overstreet DH AND YADID G. 1998. Altered gene expression for catecholamine biosynthetic enzymes and stress response in rat genetic model of depression. Brain Res Mol Brain Res 63: 133-138. 
SHINKAI K, TOYOHIRA Y, YOSHIMURA R, TSUTSUI M, UENO S, NAKAMURA J AND YANAGIHARA N. 2007. Stimulation of catecholamine synthesis via activation of p44/42 MAPK in cultured bovine adrenal medullary cells by milnacipran. Naunyn Schmiedebergs Arch Pharmacol 375: 65-72.

Shinkai K, Yoshimura R, TOYOHIRA Y, UENO S, TSUTSUI M, NAKAMURA J AND YANAGIHARA N. 2005. Effect of prolonged exposure to milnacipran on noradrenaline transporter in cultured bovine adrenal medullary cells. Biochem Pharmacol 70: 1389-1397.

SPASOJEVIC N, GAVRILOVIC L AND DRONJAK S. 2008. Different behavioral effects of maprotiline and fluxilan in rats. Arch Biol Sci 60: 33-39.

SPASOJEVIC N, GaVRILOVIC L, Jovanovic P AND DRONJAK S. 2011. Flouxetine treatment acts selectively increasing myocardial betal-adrenoceptor mRNA expression in stress-induced depression. Pharmazie 66: 611-613.

SUTER-Crazzolara C, LACHMUND A, ARAB SF AND UNSICKER K. 1996. Expression of neurotrophins and their receptors in the developing and adult rat adrenal gland. Brain Res Mol Brain Res 43: 351-355.

Szot P, Ashliegh EA, Kohen R, Petrie E, Dorsa DM AND VEITH R. 1993. Noradrenaline transporter mRNA is elevated in the locus coeruleus following short- and longterm desipramine treatment. Brain Res 618: 308-312.

TANK AW, CURELla P AND HAM L. 1986. Induction of mRNA for tyrosine hydroxylase by cyclic AMP and glucocorticoids in a rat pheochromocytoma cell line: evidence for the regulation of tyrosine hydroxylase synthesis by multiple mechanisms in cells exposed to elevated levels of both inducing agents. Mol Pharmacol 30: 497-503.
Thome J, Sakai N, Shin K, Steffen C, Zhang YJ, Impey S STORM D AND DUMAN RS. 2000. Cyclic AMP response element-mediated gene transcription is upregulated by chronic antidepressant treatment. J Neurosci 20: 4030-4036.

Tillinger A, Sollas A, Serova Li, Kvetnansky R and SABBAN EL. 2010. Vesicular monoamine transporters (VMATs) in adrenal chromaffin cells: stress-triggered induction of VMAT2 and expression in adrenaline synthesizing cells. Cell Mol Neurobiol 30: 1459-1465.

WAKAdE AR, WAKADE TD, POOSCH M AND BANNON MJ. 1996. Noradrenaline transport and transporter mRNA of rat chromaffin cells are controlled by dexamethasone and nerve growth factor. J Physiol 494: 67-75.

WEIHE E, SCHÄFER MK, ERICKSON JD AND EIDEN LE. 1994. Localization of vesicular monoamine transporter isoforms (VMAT1 and VMAT2) to endocrine cells and neurons in rat. J Mol Neurosci 5: 149-164.

Willner P, Muscat R AND PAPP M. 1992. Chronic mild stress-induced anhedonia: a realistic animal model of depression. Neurosci Biobehav Rev 16: 525-534.

YASUMOTO S, TAMURA K, KARASAWA J, HASEGAWA R, IKEDA K, YAMAMOTO T AND YAMAMOTO H. 2009. Inhibitory effect of selective serotonin reuptake inhibitors on the vesicular monoamine transporter 2. Neurosci Lett 454: 229-232.

Zavosh A, Schaefer J, Ferrel A AND FiglewiCZ DP. 1999 Desipramine treatment decreases $3 \mathrm{H}$-nisoxetine binding and noradrenaline transporter mRNA in SK-N-SHSY5Y cells. Brain Res Bull 49: 291-295. 